\title{
CRAYFISHERIES IN FINLAND, A SHORT OVERVIEW
}

\author{
J. JUSSILA (1, 2), A. MANNONEN (1)
}

(1) Crayfish Innovation Center, Päijänne-Institute, Meijeritie 1, 17200 Vääksy, Finland. E-Mail: raputietokeskus@jippii.fi

(2) The Institute of Applied Biotechnology, The University of Kuopio, P.O. Box 1627, 70211 Kuopio, Finland

Reçu le 7 janvier 2004

Received January 7, 2004

Accepté le 11 juin 2004

Accepted June 11, 2004

\begin{abstract}
Crayfish trapping and activities related to crayfishing have traditionally been lucrative businesses in rural Finland. The catch itself, varying in the 1990's from 2 to 4 millions crayfish annually, is worth 4 to 8 millions euros. Crayfishing has been a crucial part of small-scale business farms with access to productive crayfish stocks. The catch has so far been mainly noble crayfish (Astacus astacus) but stockings with signal crayfish (Pacifastacus leniusculus) during the past 15 years have started to produce commercial scale catches in Southern Finland. This has had a strong impact on commercial markets and has encouraged stocking of signal crayfish to an increasing number of water bodies, both legally and illegally. Noble crayfish stocks, on the other hand, have suffered from crayfish plague (Aphanomyces astaci) and watercourse construction. Up to 10 commercially productive noble crayfish stocks have been infected with crayfish plague annually. Most of the signal crayfish stocks have been infected as well, with the price being paid in loss of commercial value and even population collapse. The traditional way to catch crayfish is trapping during the crayfish season, with an increasing number of crayfish farmers competing for the same markets. Crayfish tourism is also taking its first steps, with a lot of opportunities for services targeted at urban upper class customers both in domestic and foreign markets. The future of Finnish crayfisheries remains uncertain at the moment with the following processes under way: spread of signal crayfish northwards, spread of crayfish plague, declining noble crayfish catch, restructuring of the commercial crayfish markets into several fractions, increasing demand for noble crayfish stockings, increasing demand for market size noble crayfish and demand for processed crayfish.
\end{abstract}

Key-words: crayfish, catch, wild stocks, disease, business.

\section{PÊCHE DES ÉCREVISSES EN FINLANDE, UN BREF APERÇU}

\section{RÉSUMÉ}

La capture d'écrevisses à l'aide de nasses et les activités liées à la pêche des écrevisses sont traditionnellement des activités lucratives dans le monde rural finlandais. Dans les années 1990, 2 à 4 millions d'écrevisses sont capturées annuellement, rapportant entre 4 et 8 millions d'euros. La pêche des écrevisses a joué un rôle économique crucial pour les petites exploitations agricoles ayant accès aux stocks productifs d'écrevisses. Cette pêche visait principalement l'écrevisse noble (Astacus astacus) mais les repeuplements 
en écrevisses signal (Pacifastacus leniusculus) durant les 15 dernières années ont favorisé le développement de pêches à but commercial dans le Sud de la Finlande. Ceci a eu un important impact commercial et a encouragé les repeuplements, légaux et illégaux, d'écrevisses signal dans un nombre croissant de cours d'eau.

D'autre part, les stocks d'écrevisse noble ont souffert de la peste des écrevisses (Aphanomyces astaci) et des aménagements de cours d'eau. La peste des écrevisses a infecté chaque année jusqu'à 10 populations commercialement productives. De même, la plupart des stocks d'écrevisses signal ont été infectés, avec pour conséquence une baisse de la valeur marchande et même un effondrement des populations.

La manière traditionnelle de capturer des écrevisses est le piégeage et le nombre de fermiers en concurrence sur les marchés est en augmentation. Le tourisme de l'écrevisse prend également son premier essor, permettant le développement de nombreux services à l'intention des classes sociales urbaines aisées, locales ou étrangères. L'avenir des activités astacicoles finlandaises reste incertain à l'heure actuelle du fait des processus suivants: propagation des écrevisses signal au nord, propagation de la peste des écrevisses, diminution des captures d'écrevisse noble, restructuration et fractionnement du marché de l'écrevisse, demande croissante de repeuplements en écrevisses nobles, demande croissante d'écrevisses nobles de taille commercialisable et demande d'écrevisses transformées.

Mots-clés : écrevisse, pêche, stocks naturels, maladie, business.

\section{INTRODUCTION}

The crayfisheries in Finland go back at least 150 years, with peak catches during the turn of the $20^{\text {th }}$ century (LEHTONEN, 1975). Most of the catch was exported to St. Petersburg and Sweden and at its best some 20 million crayfish were giving vital income to rural crofters. Quite soon the crayfish plague (Aphanomyces astaci) and the massive exploitation of the wild stocks resulted in the collapse of the crayfisheries, and the number of crayfish trapped declined and remained close to between 2 and 5 million crayfish for decades to come. The crayfish plague infected most of the wild noble crayfish stocks (WESTMAN et al., 1973; WESTMAN and NYLUND, 1984), some even several times, during the following century and kept the catch at a low level. There were also other major manmade changes in the aquatic environment that further diminished the habitat suitable for crayfish (WESTMAN, 1985; MATERO and SAASTAMOINEN, 1998).

Even this low catch allowed a lively crayfish culture with a limited trapping season and prosperous crayfish festivities to develop (FORSMAN et al., 1994; EDER and HÖDL, 1998; FÜRST and TÖRNGREN, 2003). In time, the tradition was adopted by all social classes in Finland, even with the increased price of noble crayfish (JUSSILA, 1995; JUSSILA and MANNONEN, 1995). The demand for live crayfish has remained high until today.

The industrialisation and construction of watercourses in Finland slowly changed the picture again. Crayfish disappeared from the large lakes in southern Finland and large rivers in western Finland due to both the changes in the environment and the effects of crayfish plague. One possible cause to this problem was seen in the form of signal crayfish (Pacifastacus leniusculus) which had coexisted with crayfish plague in North America under quite similar conditions to the Scandinavian aquatic environment (ABRAHAMSSON, 1973; WESTMAN, 1985; HOLDICH and LOWERY, 1988; KIRJAVAINEN and WESTMAN, 1999; SKURDAL et al., 1999; WESTMAN, 2000; KILPINEN, 2003). Signal crayfish were introduced to Finland in the late 1960's, stocked in several water bodies with varying success in the 1970's and later, in the 1980's and 1990's, in massive stockings to larger lakes in Southern Finland. As a result of the stocking programs, the catch of signal crayfish 
finally reached commercial level after the turn of the millennium and caused another interesting turn in the Finnish crayfisheries.

This paper shortly introduces the latest information on Finnish crayfisheries with emphasis on the cultural, ecological and economical aspects of the two co-existing species in the scattered waterbodies in Finland. We also consider the future of the Finnish crayfisheries.

\section{SPECIES IN FINLAND}

There are three freshwater crayfish species in Finnish water bodies, namely noble crayfish (Astacus astacus), signal crayfish (Pacifastacus leniusculus) and narrow clawed crayfish (Astacus leptodactylus). The two first species are of commercial value both in terms of the catch and price per individual. The narrow clawed crayfish exist in some lakes in Eastern Finland (SKURDAL et al., 1999), with the latest report of a small population in lake Kivijärvi (2003), and for the previous 30 years in the same region but in a different lake.

The official crayfish strategy, which has official status but is not part of legislation as such, sets tight guidelines for the stocking and spreading of signal crayfish in Finland (Figure 1) (MANNONEN et al., 2000; MANNONEN, 2001). The purpose of the strategy is to confine signal crayfish to the waters of Southern Finland by means of stocking licence policy. Also, the farming of signal crayfish is discouraged outside of this region by not subsidising farming investments. Unfortunately, signal crayfish have been stocked to several water bodies outside this territory, before the first version of the official strategy was agreed in 1989. Furthermore, the stockings of signal crayfish were strongly promoted in the 1980's, which further helped to spread signal crayfish. As a result, signal crayfish have taken up a strong position in southern lakes, as was intended, but are slowly spreading northwards, mostly due to illegal stockings.

The noble crayfish has traditionally been stocked to most of the available water bodies in Finland since the discovery of its commercial value 150 years ago. The stockings were of major economic importance during the mid and late 1800's and have since held a steady position in the stocking programs and fisheries management plans all over Finland. Many Finnish water bodies have been stocked with noble crayfish several times due to crayfish plague and other factors causing mass mortalities in established noble crayfish stocks. This has resulted in numerous productive noble crayfish stocks but, on the other hand, has led to a possible loss of diversity because genetically different stocks have been mixed over time.

\section{CRAYFISH TRAPPING}

The most common way to catch crayfish on a recreational and professional level is using baited traps of varying designs (LEHTONEN, 1975; WESTMAN and NYLUND, 1984; JUSSILA, 1995; JUSSILA et al., 1995). Traps are normally set close to the shoreline to depths of 1 to 10 meters, depending on the species trapped and lake characteristics. Traps are usually set in the evening before sunset and collected the following morning, when crayfish are removed and fresh baits are put in the traps. There are several more primitive and traditional crayfish catching methods still being used, like dip nets, baited rod and line and even catching by hand. Crayfish collection by scuba has also been introduced as a recreational and scientific method.

Fishing licences as well crayfishing licences are usually privately owned. By law, these families have been organised as local fishery collectives that regulate the fishery and manage the fish and crayfish stocks. Crayfish have traditionally been a highly priced, 
Distribution of noble crayfish (WESTMAN 1973)

Area designated for signal crayfish

O Occurence of narrow clawed crayfish
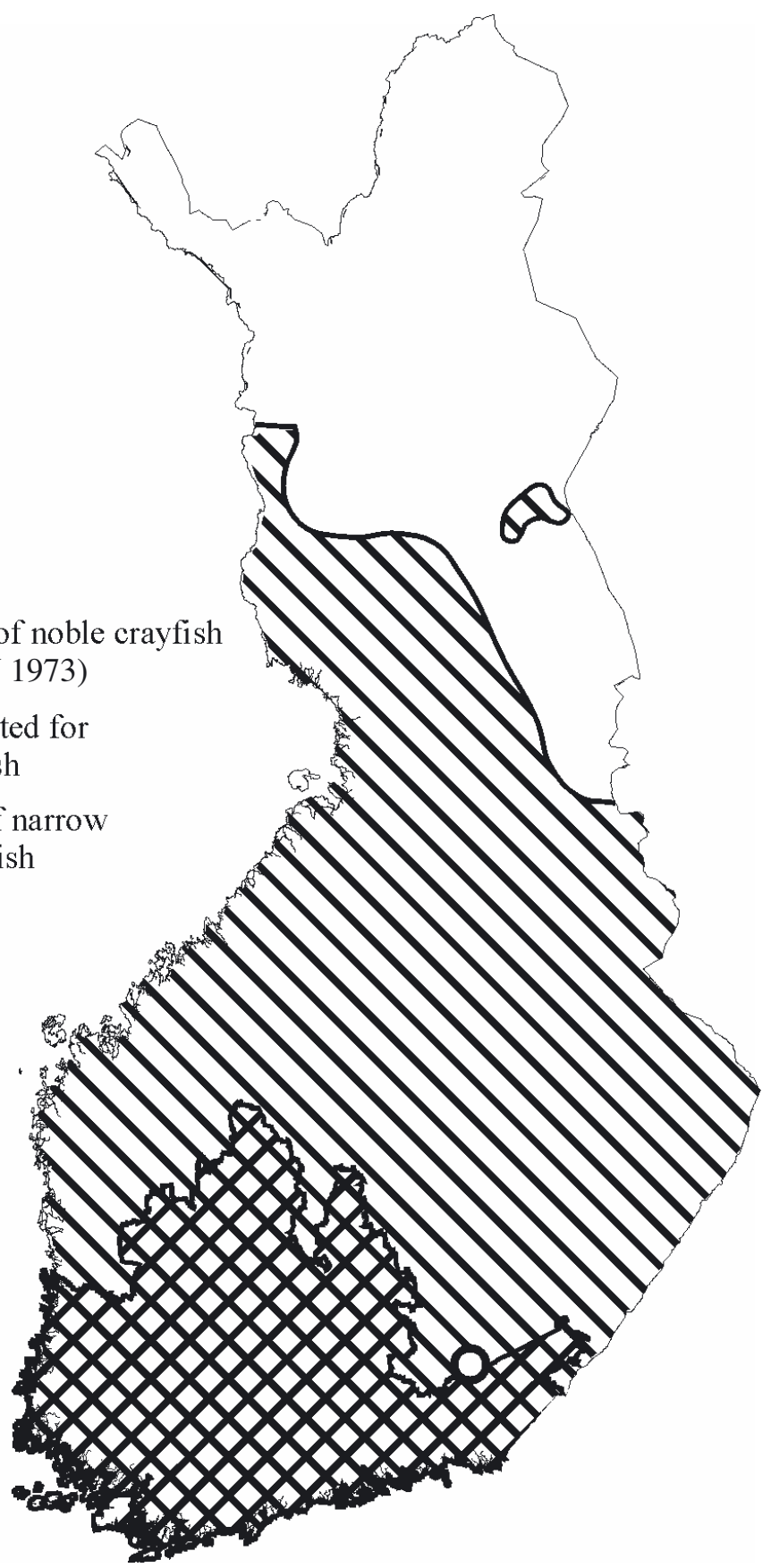

Figure 1

Distribution of noble crayfish, the designated area for signal crayfish and narrow clawed crayfish in Finland, according to the National crayfish strategy (MANNONEN et al., 2000) and data collected by Crayfish Innovation Center and Finnish Game and Fisheries Research Institute, Helsinki, Finland (WESTMAN, 1973).

\section{Figure 1}

Distribution des écrevisses nobles, secteur indiqué pour les écrevisses signal et les écrevisses à pattes grêles en Finlande, selon la Stratégie nationale pour les écrevisses (MANNONEN et al., 2000) et les données du Crayfish Innovation Center et du Finnish Game and Fisheries Research Institute, Helsinki, Finland (WESTMAN, 1973). 
lucrative catch and the trapping licences are rarely sold to outsiders and are often expensive. Thus illegal trappers are heavily punished. The licensing system varies from one lakeside to another, depending on local customs and preferences. The licence fee per trap can be as high as 5 to 10 euros, and in some cases the lakeside is divided into individual trapping sites, which are sold to trappers in auctions. Prices for the best sites can be as high as 500 to 1000 euros each per season. Quite recently, the first professional crayfishermen since last century have started exploiting signal crayfish stocks, with 8 crayfishermen in lake Pyhäjärvi (Säkylä) using a total of 1600 traps during the crayfish season this year.

The trapping season is limited from July 21 noon to the end of October in Finland. The reason behind the limited trapping season is to protect berried females, which may carry eggs until mid July (NISKANEN et al., 1998; HOLDICH, 2002). If spring and summer are delayed in Southern Finland and, in Northern Finland even in normal summers, female crayfish are often carrying eggs when the season begins.

\section{CRAYFISH CATCH}

The crayfish catch has traditionally been only noble crayfish, with its annual catch being up to almost 20 million crayfish during the first years of the last century (Figure 2) (LEHTONEN, 1975; WESTMAN and NYLUND, 1984). Since then the total catch has declined dramatically and during recent years the signal crayfish catch has increased. In the last Finnish Game and Fisheries Research Institute (FGFRI) survey carried out in 2002, the total catch was estimated to be 3.1 million crayfish out of which we estimated 1 million

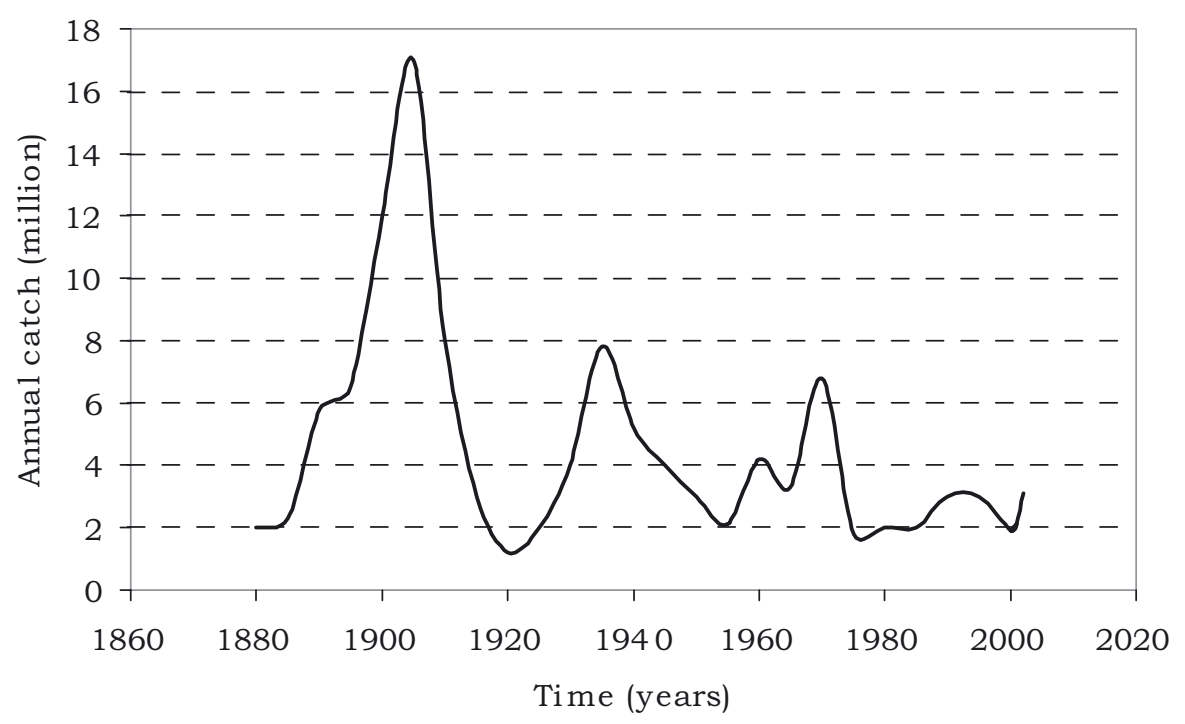

\section{Figure 2}

Catch of crayfish in Finland during the recorded history of commercial crayfish trapping. The figure is drawn according to WESTMAN (1984) and more recent data from Finnish Game and Fisheries Research Institute, Helsinki, Finland.

\section{Figure 2}

Capture d'écrevisses en Finlande d'après les enregistrements historiques des captures commerciales. La figure est établie d'après les données de WESTMAN (1984) et celles, plus récentes, du «Finnish Game and Fisheries Research Institute", Helsinki, Finlande. 
to be signal crayfish. The signal crayfish catch has been estimated to double every other year for a few years and some experts have estimated that the total catch could be close to 10 million by the year 2010. Thus, the increasing signal crayfish catch increases the total crayfish catch significantly.

The annual catch is trapped mostly from the wild, with an estimated $99 \%$ of the crayfish trapped from lakes and rivers. The production of market size crayfish in crayfish farms is very hard to estimate, but production still remains low with about 100 000-200 000 mostly signal crayfish being produced annually.

\section{THE CRAYFISH MARKET}

Most of the crayfish are sold live, with trappers and farmers selling either directly to customers or to local traders. The crayfish, before reaching consumers, goes through several trading levels ( 1 to 3 levels normally), which increases the price of the crayfish. Recently the proportion of processed (cooked, marinated, frozen, etc.) crayfish in the market has been slowly increasing.

The price of the crayfish is based on the demand-supply automate (JUSSILA et al., 1990; JUSSILA, 1995; JUSSILA et al., 1995), which largely dictates the prices according to trading traditions with also several other factors (catch predictions, stock market changes, gross scale economic trends, etc.) influencing fluctuating markets. Crayfish markets have thus been largely out of reach of regulators. The crayfish markets in Finland have traditionally been part of the grey economy (JUSSILA, 1993), i.e. the primary producers, crayfish trappers and even some of the farmers avoid reporting their catches or sales to the authorities, including tax authorities.

The crayfish prices fluctuated within certain limits, regardless of the size of the catch and overall economic environment and crayfish have traditionally been highly priced. In the 1980's the price of market size noble crayfish (10 to $11 \mathrm{~cm} \mathrm{TL}$ ) was between 1.5 and 2 euros each. The price declined during the early 1990's recession to reach a low of 1.02 euros in 1995 (Table 1). Since then the price of noble crayfish again increased and an $11+\mathrm{cm}$ noble crayfish was worth 3-4 euros (even $10+\mathrm{cm}$ noble crayfish were priced from 2 to 2.5 euros each in the season of 2003).

The markets have gone through a severe price restructuring since signal crayfish entered Finnish crayfish markets. The first Finnish signal crayfish were highly priced, especially large clawed males. Prices in the mid 1990's varied from 2.5 to 4 euros each. The price has since declined, due to material and immaterial reasons, and during the last few years the average price of signal crayfish has been from 1.5 to 2 euros each. Furthermore, there is a market for small (from 9 to $11 \mathrm{~cm} \mathrm{TL}$ ) signal crayfish for 0.5 euros each in the crayfish processing industry, which further confuses the price structure of crayfish markets.

The reasons for the diversified price structure in the Finnish crayfish markets (Figure 3) are largely based on consumer attitudes and much less on the possible differences in taste or flesh texture of the two commercial species. It has been shown that consumers cannot tell the difference of the two species based on taste of the flesh in several popular taste tests and newspaper articles. The reasons commonly mentioned behind the price deviation are: flesh taste, shell hardness, crayfish plague spots and origin of species. Finnish crayfish consumers have traditionally relied on noble crayfish and they are still willing to pay a premium price for the so-called native crayfish. Since the price of crayfish in general is largely based on consumers' image of the product and the consumer status surplus of noble crayfish, the rational basis for the price difference is quite difficult, if not impossible, to analyse and explain. 


\section{Table 1}

Combined mean price for noble crayfish and signal crayfish in Finland in 19932002, data from selected traders $(n=23)$ from Southern Finland (personal communication Eija Nylander Finnish Game and Fisheries Research Institute, Helsinki, Finland).

\section{Table 1}

Prix moyen cumulé des écrevisses nobles et des écrevisses signal en Finlande en 1993-2002, données de commerçants sélectionnés $(n=23)$ en Finlande méridionale (communication personnelle Eija Nylander Finnish Game and Fisheries Research Institute, Helsinki, Finland).

\begin{tabular}{lcc}
\hline & each & $\begin{array}{c}\text { each } \\
\text { (price adjusted to 2002 level) }\end{array}$ \\
\hline 1993 & 1.31 & 1.50 \\
1994 & 1.12 & 1.27 \\
1995 & 1.02 & 1.15 \\
1996 & 1.56 & 1.75 \\
1997 & 1.54 & 1.71 \\
1998 & 1.93 & 2.11 \\
1999 & 1.98 & 2.13 \\
2000 & 2.10 & 2.19 \\
2001 & 2.24 & 2.27 \\
2002 & 1.87 & 1.87 \\
\hline
\end{tabular}

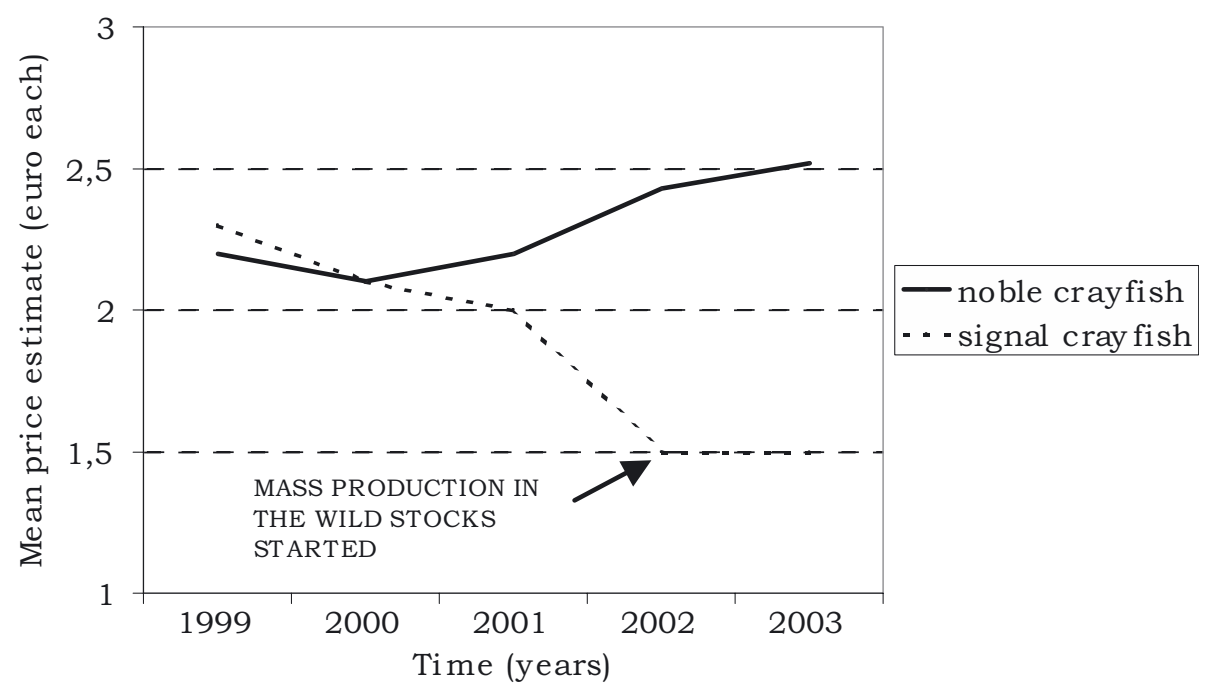

Figure 3

Price differentiation of the two commercial crayfish, noble crayfish and signal crayfish, in Finland during the past years. The average price is an estimate based on data collected by Crayfish Innovation Center and should be taken as a guideline figure.

Figure 3

Différence de prix entre les deux écrevisses commerciales, l'écrevisse noble et l'écrevisse signal, en Finlande, ces dernières années. Le prix moyen est une évaluation d'après les données du Crayfish Innovation Center, et doit être pris à titre indicatif. 


\section{CRAYFISH PLAGUE}

The crayfish plague entered Finland about 110 years ago (WESTMAN et al., 1973; HOLDICH and LOWERY, 1988), most probably with the crayfish traders transferring infected crayfish from one waterbody to the next. Due to the nature of Finnish watercourses and the fact that the cause of plague was not known, the disease spread quickly across Finland and the crayfish catch collapsed within two decades. Ever since, crayfish plague has spread around Finland and caused mass mortalities every year among productive noble crayfish populations. After the introduction of signal crayfish in Finland in 1967, the plague has also infected signal crayfish stocks and most of the wild signal crayfish stocks are now chronically infected. However, there are still some 30 signal crayfish stocks in Southern Finland that are known to be free of crayfish plague, at least on the basis of absence of gross symptoms. Some of these signal crayfish stocks coexist with noble crayfish.

The diagnosis of crayfish plague is carried out by the National Veterinary and Food Research Institute of Finland (NVFRI), which has four regional laboratories. Crayfish plague diagnostics has recently been focused on the Kuopio laboratory, where the fungus is isolated and identified and detailed DNA analyses are carried out. Sometimes the plague hits a lake during the closed season and the crayfish vanish unobserved and unsampled. Also due to lack of expertise among the crayfish trappers, some of the samples are poorly handled before being sent to the laboratory and they arrive at the laboratory in such a condition that analyses can not be carried out properly. This results in quite a large proportion of the samples being discarded. Also, some of the samples are obviously healthy individuals. For these reasons there have been cases of contrasting information given out by the NVFRI regional labs on crayfish from the same stock. This further complicates the fight against the spreading of crayfish plague.

A recent discovery has shown that there are at least two different strains of crayfish plague currently in Finland (VENNERSTRÖM et al., 1998). The first crayfish plague fungus strain was recorded in Southern Europe in the 1860's and the second strain was probably introduced with the more recent introduction of signal crayfish in Sweden and Finland. So far, the original crayfish plague fungus mostly infects noble crayfish in Eastern Finland and the other strain seems to be infecting signal crayfish stocks in Western Finland, thus the strains are commonly called eastern and western type fungus. The clear pattern is changing slowly, with the western type making its way towards east and north and infecting noble crayfish populations. The differences in virulence and life cycle of these two types of plague are not known.

Crayfish plague gives another advantage to signal crayfish in the competition for Finnish water bodies with noble crayfish. In addition to signal crayfish being more competitive with bigger claws and more aggressive nature (EDSMAN and JONSSON, 1996; WESTMAN, 2000; WESTMAN and SAVOLAINEN, 2001; HOLDICH, 2002), the fact that signal crayfish can carry crayfish plague as a chronic, sub lethal infection, gives next to no chance to noble crayfish. Unfortunately, illegal and poorly planned introductions of signal crayfish have clearly shown how effective crayfish plague can be.

\section{FUTURE PROSPECTS}

The crayfish, both noble and signal, will have an important role in Finnish culture in the future. The main threat for both species is crayfish plague, even with the possibility of other epizootics, such as viruses, having a role in the ecosystem. From the commercial point of view, crayfish plague is extremely devastating, since it totally wipes out noble crayfish stocks, and also affects the market value of signal crayfish. At the same time signal crayfish, the plague and environmental changes are pushing noble crayfish to smaller, more remote upstream water bodies. Finnish crayfish farmers have particularly 
noticed this when consumers insist on paying less for plague affected signal crayfish. The melanised spots can easily be spotted on boiled crayfish as black spots. Furthermore, the signal crayfish is slowly making its way northwards in Finland, putting more pressure on noble crayfish. The spread of signal crayfish is due to both legal and illegal stockings and even the local government fisheries authorities have tended to ignore the guidelines given in the National crayfish strategy at times.

The noble crayfish catch is slowly declining, due in part to the spread of both crayfish plague and signal crayfish. The worst-case scenario is that there would not be any commercially viable noble crayfish populations in Finland in 30 years from now. The value of the noble crayfish catch does however decline slowly, since consumers are willing to pay handsomely for the remaining noble crayfish. Traditionally, it has been a luxury food in restaurants and at crayfish parties during the crayfish season, and smaller supply results in higher price. Unfortunately, the high prices do not help to support widespread crayfish related culture in Finland.

Crayfish tourism is slowly picking up in rural areas. Crayfish have been seen as a valuable annex to small-scale hospitality businesses. Several small-scale farmers have added crayfish parties or crayfish trapping to the list of services on their farms. The customers are also paying attention to this new nature related experience, which is giving easy access to the partially forgotten cultural world of crayfishing and crayfish parties.

The demand for noble crayfish stockings is set to increase in the future, and even now the first signs of increasing demand can be seen. Some of the crayfish farmers are already switching from signal crayfish production to at least partially producing noble crayfish for stockings into the wild and to other farms. Furthermore, the production of noble crayfish on farms becomes more profitable if the noble crayfish is more highly valued than signal crayfish among customers.

Finally, there could be a market for processed crayfish, such as marinated tail meat, mainly because of the increasing catch of wild signal crayfish. Currently, mass production of cooked and frozen signal crayfish has started in Finland, with 100000 crayfish been processed in 2002 and some 250000 crayfish during 2003. This has also produced a market for small, $9-11 \mathrm{~cm}$ TL, signal crayfish for the beach price of 0.50 euros each. There are several other options for more sophisticated crayfish products in Finnish markets.

\section{ACKNOWLEDGEMENTS}

We would firstly like to thank our financer, Unemployment and Economic Development Centre (T\&E Centre) in Häme, for funding our office and several other crayfish activities in Finland under the Financial Instrument for Fisheries Guidance (FIFG). We would like to express our gratitude to Mr. Heikki Niskanen (AKFD) for his ideas and encouragement. CRAYNET has, thankfully, shown its usefulness even before the halfway mark.

\section{REFERENCES}

ABRHAMSSON S., 1973. The crayfish, Astacus astacus in Sweden and the introduction of the American crayfish Pacifastacus leniusculus. Freshwater Crayfish, 1, 28-40.

EDER E., HÖDL W., 1998. Fluss Krebse Österreichs. Gutenberg, Linz, Austria. 284 p. (In German);

EDSMAN L., JONSSON A., 1996. The effect of size, antennal injury, ownership, and ownership duration on fighting success in male signal crayfish, Pacifastacus leniusculus (Dana). Nordic Journal of Freshwater Research, 72, 80-87. 
FORSMAN L., GÖRMAN G., C.G., HALLING B., LARSSON G., PERNFORS B., PERSSON B., 1994. Kräftans lov. En kulinarisk och historisk resa i kräftans värld. Ráben Prisma/Görmangruppen, 143 p. (In Swedish).

FÜRST M., TÖRNGREN K., 2003. Våra älskade kräftor. Bäckströms Förlag, Stockholm. 118 p. (In Swedish).

HOLDICH D.M., LOWERY R.S., 1988. Freshwater crayfish. Biology, management and exploitation. Croom Helm, London. 498 p.

HOLDICH D.M., 2002. Biology of freshwater crayfish. Blackwell Scientific, London. $702 \mathrm{p}$.

JUSSILA J., HYYTINEN L., LINDQVIST O.V., 1990. Ravustuksen kustannuksista ja ravun tuottajahinnasta Mikkelin läänissä. Suomen kalastuslehti, 97 (7), 291-293 (In Finnish).

JUSSILA J., 1993. Ravustuksen kustannuksista ja kannattavuudesta Mikkelin läänissä vuosina 1989-1990 ja Vaasan läänissä vuonna 1992. Licentiate thesis. Department of Applied Zoology, University of Kuopio, Kuopio, Finland (In Finnish).

JUSSILA J., 1995. On the costs of crayfish trapping in Central Finland in 1989-90. Freshwater Crayfish, 9, 215-227.

JUSSILA J., MANNONEN L., 1995. Crayfish culture in Finland, Northern Europe. Marron Growers' Bulletin, 17 (1), 2-6.

JUSSILA J., MANNONEN L., KIRJAVAINEN J., 1995. Crayfish trapping in Finland, Northern Europe. Marron Growers' Bulletin, 17 (3), 13-15.

KILPINEN K., 2003. Suomen rapu. Ravun nousu, tuho ja tulevaisuus. Edita, Helsinki. 246 p. (In Finnish).

KIRJAVAINEN J., WESTMAN K., 1999. Natural history and development of the introduced signal crayfish, Pacifastacus leniusculus, in a small, isolated Finnish lake, from 1968 to 1993. Aquatic Living Resources, 6, 387-401.

LEHTONEN J.U.E., 1975. Kansanomainen ravustus ja rapujen hyväksikäyttö Suomessa. Kansantieteellinen arkisto, Suomen muinaismuistoyhdistys, Helsinki. 159 p. (In Finnish).

MANNONEN A., HALONEN T., TYÖRYHMÄ T.-K., 2000. Kalataloushallinnon rapustrategia. Maa- ja metsätalousministeriö, Hämeenlinna. 44 p. (In Finnish).

MANNONEN A., 2001. Uusi rapustrategia. Vesitalous, 3, 26-29. (In Finnish).

MATERO J., SAASTAMOINEN O., 1998. Monetary assessment of the impacts of forestry on water-based benefits in Finland. Boreal Environmental Research, 3 (1), 87-96.

NISKANEN H., JUSSILA J., MANNONEN A., 1998. Variation in pleonite width in wild noble crayfish (Astacus astacus) females in relation to glair gland development. Freshwater Crayfish, 11, 378-383.

SKURDAL J., TAUGBØL T., BURBA A., EDSMAN L., SÖDERBÄCK B., STYRISHAVNE B., TUUSTI J., WESTMAN K., 1999. Crayfish introductions in the Nordic and Baltic countries. In Crayfish in Europe as alien species. How to make the best out of a bad situation?, F.R. SCHRAM (Ed.), 193-220. A.A. Balkema, Rotterdam.

VENNERSTRÖM P., SÖDERHÄLL K., CERENIUS L., 1998. The origin of two plague (Aphanomyces astaci) epizootics in Finland on noble crayfish, Astacus astacus. Annales Zoologici Fennici, 1 (35), 43-46. 
WESTMAN K., 1973. The population of the crayfish, Astacus astacus L. in Finland and the introduction of the American crayfish Pacifastacus leniusculus Dana. Freshwater Crayfish, 1, 41-55.

WESTMAN K., SUTELA J., KITTI J., SUMARI O., 1973. Rapuruton esiintymisalueet Suomessa vuosina 1893-1972 (English abstract). Riista- ja kalatalouden tutkimuslaitos, Helsinki.

WESTMAN K., NYLUND V., 1984. Rapu ja ravustus. Weilin+Göös, Espoo. 173 p. (In Finnish).

WESTMAN K., 1985. Effects of habitat modification on freshwater crayfish. In: Habitat modification and freshwater fisheries. Proceedings of the European inland fisheries advisory commission, Aarhus, Denmark, 1984, (Ed.), 245-255. FAO, London.

WESTMAN K., 2000. Comparison of the crayfish Pacifastacus leniusculus Dana, a species introduced into Finland, with the native species, Astacus astacus L., in allopatry and sympatry. Doctoral dissertation. Department of Limnology and Environmental Protection, University of Helsinki, Helsinki.

WESTMAN K., SAVOLAINEN R., 2001. Long term study of competition between two co-occurring crayfish species, the native Astacus astacus L. and the introduced Pacifastacus leniusculus Dana, in a Finnish lake. Bull Fr. Pêche et Piscic., 3 (361), 613-628. 
